\title{
Red, black or white? The dawn of colour symbolism
}

\author{
Simona Petru \\ Department of Archaeology, Faculty of Arts, University of Ljubljana, SI \\ simona.petru@ff.uni-lj.si
}

\begin{abstract}
In this paper the use of the pigments in the Paleolithic is presented, and some ideas of the symbolic meaning of colours are suggested. The colour red might have been a symbol of transformation, and as such, it was used in burials and for painting the Venus figurines. In the Slovenian Paleolithic, there is scant evidence of importance of colour and only a few finds of stones used for the grinding of the red pigment have been found.
\end{abstract}

IZVLEČEK - V članku je predstavljena uporaba barvil v paleolitiku in poskus interpretacije njihovega simboličnega pomena. Ta je najbolj očiten pri rdeči barvi, ki je morda bila simbol transformacije, kar se odraža v njeni uporabi pri pokopih in pri barvanju ženskih figur. V slovenskih paleolitskih najdiščih je le malo sledi obdelave pigmentov, tolkači, s katerimi so drobili rdeč pigment, so znani le iz treh jam.

KEY WORDS - pigments; ochre; Paleolithic; burials; Venus figurines; Slovenia

\section{Introduction}

Why do three colours - white, black and red - have an outstanding position in the palette of the first artists? It is interesting that two of these, white and black are not 'real chromatic colours' with fixed wavelengths, but more expressions of light and darkness. And yet their names are the first in the evolution of basic colour terms and they exist in all languages (Berlin \& Kay 1999). So white and black basically express what colour really is - our perception of light (white) or the absence of light (black). In Palaeolithic art some images could be the expression of a white and black colour scheme, like the black paintings on the white wall from the 'Salon Noir' in the Niaux cave (Fig. 1). Marshack found combinations of these two colours on the engraved mammoth ivory from the Russian plain. The engravings were filled with thick black paste, so the images appeared black against the white background of the ivory (Marshack 1981.189).

Red is the first 'real' colour with a defined wavelength. It is the third term that emerges in language after white and black. In languages with only a few terms for colours, the term red includes many hues, which means that it includes all reds, oranges, most yellows, browns, pinks and purples. Separate names for these colours and for other colours like blue and green evolve later (Berlin \& Kay 1999). The variety of names for colour also depends on the environment in which people are living, or on their main activity. The Damara people of Namibia have many names for the colours of livestock, since they are herders, but they lack names for green and blue, since they are not interested in them at all (Berlin and Kay 1999, with citations).

The visual and auditory senses are important for the human perception of surroundings. Colour and sound are both wave phenomena: colours are electromagnetic, while sounds are mechanical waves. As such, they have different wavelengths and different energies. Both influence our feelings. With some colours we have the impression of energy, while others calm us down; the same applies to sound. Speaking 
produces sounds. So not only words express our feelings, but also the sound of speaking itself. Different voices make different impressions on us. Some people have pleasant voices, and we react positively to them, while others may provoke negative feelings. So we communicate with sound, as well as with words, and we also communicate our feelings through colours. If talk and language are a form of social
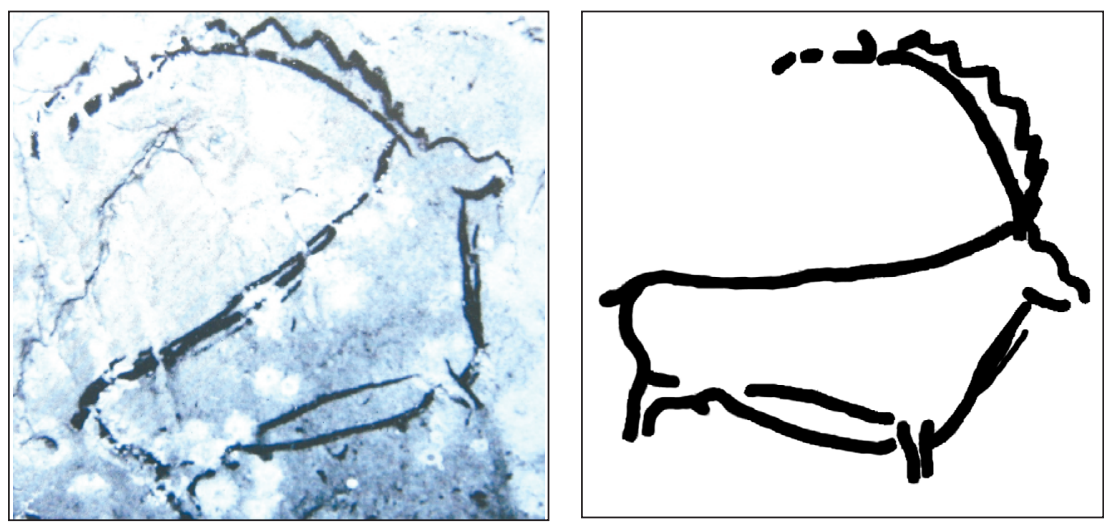

Fig. 1. Ibex from Niaux (from Graziosi 1956.Tav. 198). Black and white painting. grooming, since they influence our feelings (Dunbar 2004.114), then sound and colour are a type of grooming also. If elaborated speech emerged with modern humans, then improved communication through colour is also probably part of modern human behaviour. Refined art as an expression of feelings and as a bearer of information was possible when humans were capable of forming complex communication systems to transfer their feelings and information to others. Only in such systems was there a possibility for the perception of colours as symbols. Symbols strongly influence our feelings, just as colour does. So colours have the potential to be very powerful symbols.

It is difficult to imagine how much colour in the Palaeolithic was perceived as colour per se and how much as an essential part of a depicted object - so red might mean red ochre, not just a red hue. Even today in some languages the names for different colours are the same as the names for objects which are of that colour. In the language of the Ndembu people in Congo word amatamba that means 'water of sweet potato' leaves is used for green colour. The Aborigines in Queensland use the same word oti for blood and red colour (Berlin \& Kay, with citations 1999).

The first colorants are known from Old Palaeolithic contexts, and in some cases there are indices that they were used for colouring different objects. Bednarik (2003) claims that the naturally formed 400000 years old Tan-Tan figure was artificially modified and coated with red paint. At the Zambian site of Twin Rivers the use of ochre was known at least 200000 years ago. Minerals for the production of pigments were systematically collected and used (Barham 2002). In the Middle Palaeolithic, pigments became even more frequent. A review of the pigments found during the excavations of Bordes indicated that black and red were often present in French Mousterian (Demars 1992). In the Mousterian site of Tata a mammoth molar plaque was covered with red ochre (Marshack 1981.189). But it was in the Upper Palaeolithic that colorants became ubiquitous, and their power was expressed and preserved through art and in graves.

Black and red are quite common in Palaeolithic art, while white is almost completely absent at first sight. But it should not be forgotten that the walls on which images are depicted are frequently white. Artists produced white hues by leaving areas of limestone wall blank, or they even scraped the dust off the wall surface to create an area of white. In the painting of the 'Chinese horse' at Lascaux (Fig. 2), blank wall represents the unpainted white underbelly of the horse (Marshack 2003). That white pigments were used was confirmed in the Magdalenian cave of Bedeilhac, where a white clay plaquette was found. It was used as a crayon to colour animal hide or human skin (Marshack 2003). It is also possible that white paint was frequently used, but since it was less durable than other colours it was not preserved. Such is the case with the San paintings at Rose Cottage Cave and from other South African sites, where the parts of the paintings which were coloured white disappeared with time (Williamson 2000.755; Lewis-Williams 2002.146).

Only mineral colours are preserved for a long time, which could be the reason there is such a scarcity of colour in Palaeolithic art. There might be colours made from organic material extracted from plants or animals, but such material does not survive over the course of thousands of years. Another problem is that the extraction of plant pigments like green or blue is complicated, and the plants which could be 
used in the process grow mostly in tropical areas (Couraud 1983.107; 1988.20). The only organic pigment preserved is charcoal, which was used for black colouration. Manganese oxides were also used for black colouration. These oxides can be found on the walls of limestone caves as a product of alteration (Clottes et al. 1990.178).

Red pigments were produced from iron oxides, like hematite or limonite, and from ochre. Hematite was the most frequently used mineral. It occurs in the form of aggregates of small red crystals, or in the form of bigger black crystals, which are difficult to crush (Clottes et al. 1990). White was obtained mostly from kaolinite or illite.

Pigments were mixed together with other components to obtain colours. Extenders were added for a many reasons - to economize the consumption of pigment or to improve colour characteristics, such as different shades, adhesion and durability. Investigations in the Ariège region in France indicated that in some cases feldspar was used as an extender, while in others biotite or talc was used. Different recipes for the preparation of colour were known, and research of portable art from well-dated contexts in this region indicated that recipes could be chronologically defined. But it is also possible that the use of recipes depended on the season, the social occasion or ritual, in which case they might have had symbolic meanings (Clottes et al. 1990). Pigments themselves might also have had supernatural powers in Palaeolithic, as they had for the San people of South Africa. In San society, the transformation of the pigment into paint was accompanied by ritual procedures (Lewis-Williams 2002.255)

Sometimes different materials, such as blood, egg white or urine were added to colorants as binding. In the Rose Cottage Cave in South Africa, the pigments of San paintings were examined, and blood

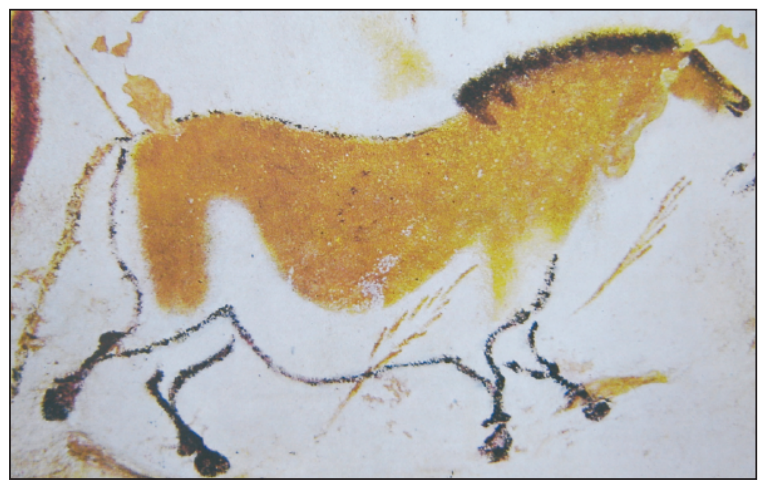

was detected as binding. It was mixed with yellow ochre, but not with red colorants. This might had symbolic meaning - yellow, that lacked the appearance of blood, needed additional 'power', so they mixed it with blood, while red was already powerful enough (Williamson 2000). Human blood protein was also a constituent of red pigment in two Australian caves dated to late Pleistocene. Art motifs in those caves consist of hand stencils and panels covered with red pigment. It is interesting that even in the recent past human blood was often used in $\mathrm{Au}$ stralian Aboriginal ritual activities (Loy et al. 1990). In France, experiments were carried out to determine the possible binding materials in Palaeolithic paintings. As Couraud found, organic substances were unsuitable, and the best binding agent was water, especially cave water rich in calcite, since it fixes and conserves pigments on the wall (Couraud 1988.23).

In some cases manganese was burnt and used for black pigment. Burning might have had practical use to facilitate the making of the pigment powder, but it might have had also symbolic and even ritual aspect. The same might be true for the burning of ochre and hematite. With burning, the colour of ochre changes from yellow to different hues of red or to violet (Leroi-Gourhan 1968.69). The burning of ochre might have already been known in the old Palaeolithic site of Terra Amata, where pieces of ochre of various colours from yellow and red to brown were found (Groenen 1991.14, with citations). Fire played important role in Paleolithic rituals, which is confirmed in Central and Eastern Europe, where clay was burnt to make figurines used in rituals (Guineau et al. 2001.222). Perhaps the early modern humans at Qafzeh cave were already burning yellow goethite to transform it into red hematite - fire was used intentionally to change the yellow colour to red (Hovers et al. 2003.502). Possibly the transformation of a yellow stone to a red one was viewed as magical (Vreschner 1980.632).

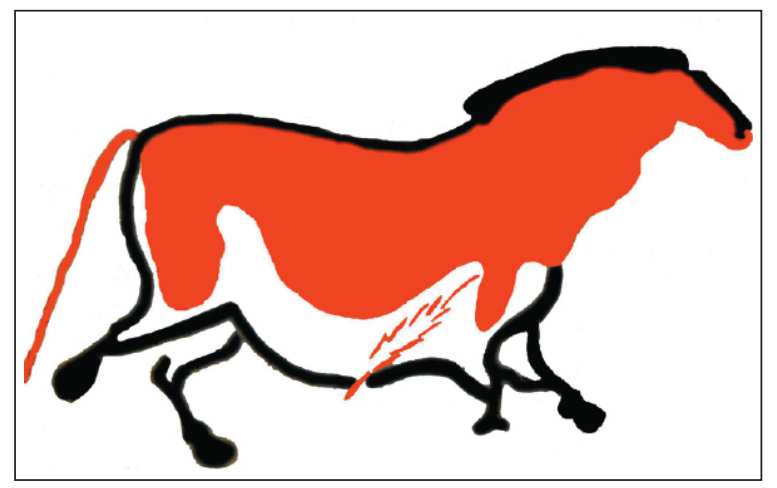

Fig. 2. 'Chinese horse' from Lascaux (from Graziosi 1956.Tav. 182). Three colour scheme painting. 
Fire also had important symbolic meaning; it was the agent of transformation. In times of cold and harsh weather, fire was indispensable, since it changed cold into warmth. If ochre is treated with fire, it is transformed and it changes colour. If clay is burnt, it changes its structure and hardness. That is probably why red was so important, since it was the symbolic colour of fire and transformation.

As a symbol of transformation red ochre is present in graves. Death is the ultimate transformation known to human beings. Ochre was used in funeral rites, probably because it passes through a powerful colour transformation when burnt. Together with the whiteness of bones and the blackness of the grave, red was part of the mighty tricolour scheme which symbolised death. As a symbol of fire, red ochre might have been sprinkled over a cold dead body to warm it up and to restore life. The early co-occurrence of the use of fire, burials and ochre is known from Qafzeh Cave in 90000 to 100000 years old layers, where the skeletal remains and burials of the first early modern humans in the Levant were found (Hovers et al. 2003.508). Hovers et al argue that ochre was selected and mined for its colour, rather than for any other property. The specific hues of red had been desired. The symbolic use of ochre is suggested rather than practical (Hovers et al. 2003). The findings from Qafzeh cave are the only certain evidence of the relation between ochre and human skeletons in Middle Palaeolithic contexts, while in the Upper Palaeolithic, ochre becomes more frequent grave good (Riel-Salvatore \& Clark 2001.454-457). It was important in mortuary rites and was present in almost half of the known burials (Groenen 1991.18).

Two interesting burials of children sprinkled with ochre are from Lagar Velho in Portugal and from
Krems in Austria. In Lagar Velho a 25000 years old burial of a child who exhibits a mix of early Modern human and Neanderthal features was found. The four years old child was covered with red ochre and laid on a bed of burnt vegetation together with pierced teeth and marine shells (Trinkaus \& Duarte 2003.32). The burial of two newborn children was found recently in Krems, Austria. The children were sprinkled with ochre and wrapped in skin, together with a necklace of mammoth ivory. The 27000 years old grave was covered with a mammoth shoulder blade. Besides the ochre, there were also other colorants found at the site: red chalk, graphite and muschelkalk - a type of limestone which was used for the production of white pigment (Einwögerer 2005).

In the Upper Palaeolithic, there was also a powerful symbolic relation between ochre and femininity (Groenen 1991.24). Many Palaeolithic venus figurines were painted with red ochre or hematite. The Venus from Mauern is completely covered with a thick layer of ochre (Mussi 1997), ochre was also found on the Venuses from the Grimaldi Caves (Bisson \& Bolduc 1994), and on two of the most famous Venuses - from Willendorf and Laussel (Bahn 1998. 75). Red colour on the female body could also have been a symbol of transformation. There is a noticeable transformation of the female body during pregnancy, which ends with the delivery of the new life. A male body never experiences such a drastic change. The concept of transformation is even more expressed in the Venus figurine from Dolní Věstonice, which is made from clay. The figurine was transformed, as it passed through fire, from a soft piece of clay into something solid and lasting. It is interesting that in San societies, the preparation of pigment was associated with women. It was a woman who had to heat the pigment at full moon until
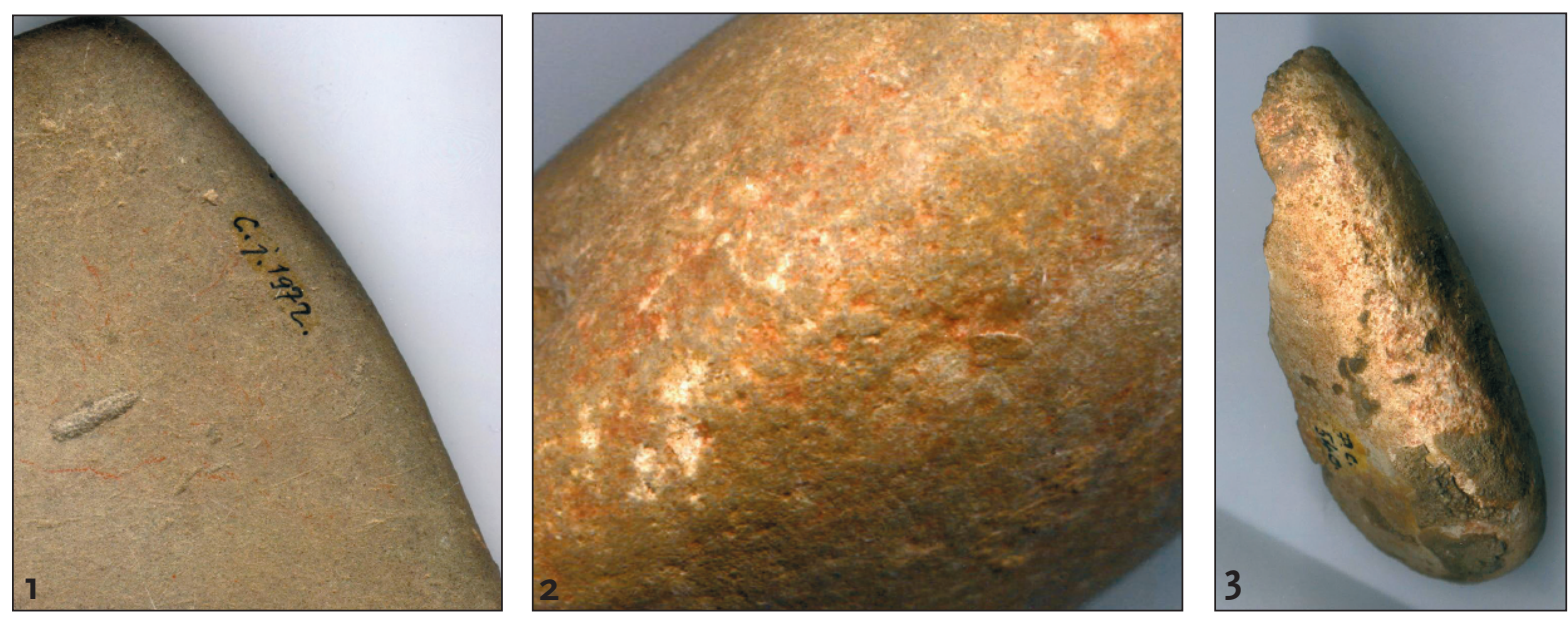

Fig. 3. Grinding stones with traces of ochre: 1. Ciganska jama, 2. Lukenjska jama, 3. Poljšiška cerkev. 


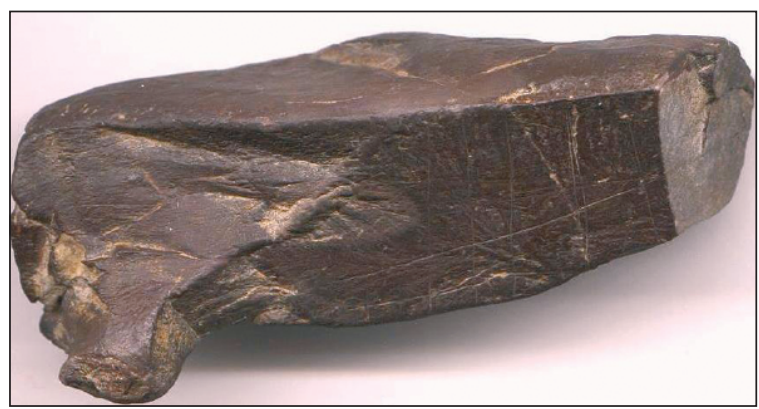

Fig. 4. Decorated stone from Zemono.

it was red hot (Lewis-Williams 2002.114, 255). In this act, femininity, burning and colour were connected as symbols of change. The act of grinding colorants was also an act of transformation from solid rock to powdered pigment, and might, together with burning, have had symbolic meaning and been accompanied with rituals.

There is another aspect of the close relation between colour and women in the Palaeolithic. After women became pregnant and had children it was difficult for them to hunt, so they had to switch to gathering. Good colour vision is indispensable for primates who are mainly dependent on gathering and collecting berries and fruits of different colours (Dominy et al. 2003), so women needed to develop excellent colour discrimination. Even today a feeling for colour is a female province, and women use more names for colour schemes than men. For hunting, colour vision is not very important, since colour-blindness doesn't affect functional ability. Consequently, defective colour vision today is nearly a hundred times more common among males than females (Gage 1999.31, 36).

As a symbol of transformation, ochre might also have been important medium during shamanistic séances, when the shaman was going through a transformation from a normal state of mind to a trance. Shamanistic healing is also a process of transformation - from sickness to health and well-being. For a South African San shaman, not just painting, but also paint in itself was powerful and trance-inducing (Lewis-Williams 2002.114).

There are only a few indices of pigment preparation from Slovenian Paleolithic sites. Grinding stones with traces of ochre are known from three Late $\mathrm{Pa}$ leolithic sites: Ciganska jama, Lukenjska jama, and Poljš̌ška cerkev (Fig. 3). In Ciganska jama a lower layer with Paleolithic stone tools was in a red zone. This zone might have been colored red with ochre,

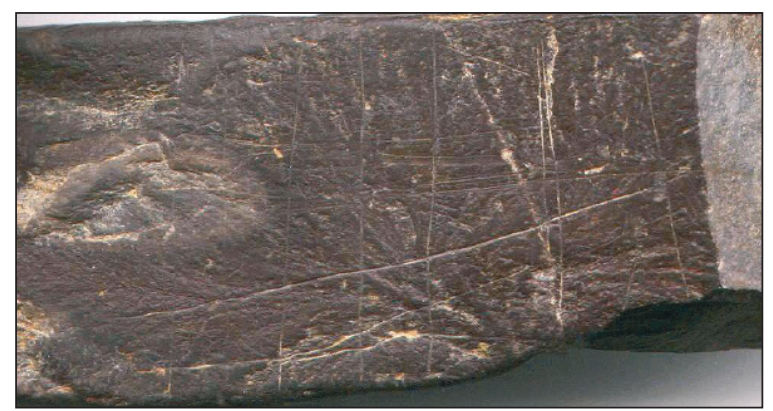

since many small grains of ochre were found there (Brodar 1991.30).

The only other evidence of the importance of red color in the Slovenian Paleolithic is a decorated stone found in Zemono. The stone has a simple pattern, composed of parallel and perpendicular lines (Fig. 4 ), and is rich in iron, so the freshly engraved lines are red, which may very well have had some symbolic significance (Petru 2005.637).

The problem of colour in the Palaeolithic is complex, and there are no easy answers to many questions regarding preparation, use, and the meaning of pigments used in art, and in everyday life. But there is no doubt that colour was an important agent of transmission of information and feelings of the first artists. Together with speech, art also developed, since people became able to express their feelings and thoughts through both, and to share the information that is the basis and reason for the evolution of language and art. 


\section{REFERENCES}

BAHN P. G. 1998. The Cambridge Illustrated History of Prehistoric Art. Cambridge University Press. Cambridge.

BARHAM L. S. 2002. Systematic Pigment Use in the Middle Pleistocene of South-Central Africa. Current Anthropo$\log y$ 43(1): 181-190.

BEDNARIK R. G. 2003. A Figurine from the African Acheulian. Current Anthropology 44(3): 405-413.

BERLIN B., KAY P. 1999. Basic Color Terms. Their Universality and Evolution. CSLI Publications. Stanford.

BRODAR M. 1991. Paleolitik Ciganske jame pri Željnah. Arheološki vestnik 42: 23-64.

BISSON M. S., BOLDUC P. 1994. Previously Undescribed Figurines from the Grimaldi Caves. Current Anthropology 35(4): 458-468.

CLOTTES J. et al. 1990. La préparation des peintures magdaléniennes des cavernes ariégeoises. Bulletin de la Société Préhistorique Française. Tome 87(6): 170-192.

COURAUD C. 1983. Pour une étude méthodologique des colorants préhistoriques. Bulletin de la Société Préhistorique Française. Tome 80(4): 104-110.

1988. Pigments utilisés en préhistoire. Provenance, préparation, mode d'utilisation. L'Anthropologie 92(1): $17-28$.

DEMARS P. Y. 1992. Les colorants dans le Moustérien $d u$ Périgord. L'apport des fouilles de F. Bordes. Préhistoire Ariégeoise 47.

DOMINY N. J., SVENNING J. C., LI W. H. 2003. Historical contingency in the evolution of primate color vision. Journal of Human Evolution 44: 25-45.

DUNBAR R. 2004. The Human Story: A new history of mankind's evolution. Faber and Faber Limited. London.

EINWÖGERER T. 2005. Die Auffindung einer jungpaläolithischen Säuglings-Doppelbestattung im Zuge neuer Ausgrabungen am Wachtberg in Krems, NÖ. Das Waldviertel 54(4): 399-404.

GAGE J. 1999. Colour and meaning. Art, Science and Symbolism. Thames and Hudson. London.

GRAZIOSI P. 1956. L'arte dell'antica età della pietra. Sansoni. Firenze.
GROENEN M. 1991. Présence de matières colorants dans l'Europe paléolithique. Anthropologie et Préhistoire 102: 9-28.

GUINEAU B., LORBLANCHET M., GRATUZE B. DULIN L., ROGER P., AKRICH R., MULLER F. 2001. Manganese Black Pigments in Prehistoric Paintings: The Case of the Black Frieze of Pech Merle (France). Archaeometry 43(2): 211225.

HOVERS E., ILANI S., BAR-YOSEF 0., VANDERMEERSCH B. 2003. An Early Case of Color Symbolism. Current Anthropology 44(4): 491-522.

LEROI-GOURHAN A. 1968. Religije Prethistorije - paleolit. Naprijed. Zagreb.

LEWIS-WILLIAMS J. D. 2002. A Cosmos in Stone. Alta-mira Press. Walnut Creek.

LOY T. H., JONES R., NELSON D. E., MEEHAN B., VOGEL J., SOUTHON J., COSGROVE R. 1990. Accelerator radiocarbon dating of human blood pigments from Late Pleistocene art sites in Australia. Antiquity 64: 110-116.

MARSHACK A. 1981. On Paleolithic Ochre and the Early Uses of Color and Symbol. Current Anthropology 22(2): 188-191.

2003. An Early Case of Color Symbolism - Comment. Current Anthropology 44(4): 514-516.

MUSSI M. 1997. Die Rote von Mauern: La "Dame rouge" de Mauern revisitée. Préhistoire Ariégeoise LII: 45-60.

PETRU S. 2005. Decorated stones from the open-air site of Zemono, Slovenia. World Archaeology 37(4): 637-640.

RIEL-SALVATORE J., CLARK G. A. 2001. Grave Markers. Middle and Early Upper Paleolithic Burials and the Use of Chronotypology in Contemporary Paleolithic Research. Current Anthropology 42(4): 449-478.

TRINKAUS E., DUARTE C. 2003. The hybrid child from Portugal. Scientific American 13(2): 32.

WILLIAMSON B. S. 2000. Direct Testing of Rock Painting Pigments for Traces of Haemoglobin at Rose Cottage Cave, South Africa. Journal of Archaeological Science 27: 755762.

WRESCHNER E. E. 1980. Red Ochre and Human Evolution: A Case for Discussion. Current Anthropology 21(5): 631644. 